\title{
Pellet gunfire injuries among agitated mobs in Kashmir
}

\author{
Keşmir'de ayaklanan grupların havalı silah saçmasıyla yaralanmaları
}

\author{
Majid MUSHTAQUE, ${ }^{1}$ Mohammad F. MIR, ${ }^{2}$ Muneer BHAT, ${ }^{3}$ Fazl Q. PARRAY, \\ Samina A KHANDAY, ${ }^{2}$ Rayees A. DAR, ${ }^{1}$ Ajaz A. MALIK ${ }^{1}$
}

\section{BACKGROUND}

Pellet gunfire injuries inflicted while controlling agitated mobs has been studied.

\section{METHODS}

A total of 198 patients admitted to the Accident and Emergency Department with pellet gun injuries were studied in terms of anatomic site, severity and type of injury, treatment, and outcomes.

\section{RESULTS}

$72.7 \%$ of patients were aged $16-25$ years. The most common sites of injury were the extremities (47.9\%), abdomen (36.3\%) and chest (31.3\%). 59.5\% of patients were found to have minor injuries. Of the 80 patients admitted to the hospital for their injuries, $43(53.7 \%)$ required an operative procedure. Six deaths $(3.03 \%)$ were observed.

\section{CONCLUSION}

While the pellet wound itself may seem trivial, if not appreciated for the potential for tissue disruption and injuries to the head, chest, and abdomen, there can be catastrophic results. Patients should be evaluated and managed in the same way as those sustaining bullet injuries.

Key Words: Pellet wounds; non-powdered guns.

\section{$\boldsymbol{A M A C}$}

Ayaklanan grupların kontrol edilirken uğradıkları saçma ile silah yaralanmaları incelendi.

\section{GEREÇ VE YÖNTEM}

Saçma tanesi ile gerçekleşen silah yaralanmaları nedeniyle kaza ve acil servis bölümüne yatırılan toplam 198 hasta, anatomik bölge, ciddiyet ile yaralanma tipi, tedavi ve sonuçlar bakımından değerlendirildi.

\section{BULGULAR}

Hastaların \%72,7'si, 16 ile 25 yaş arasında idi. En sık yaralanma bölgeleri ekstremiteler $(\% 47,9)$, karın $(\% 36,3)$ ve göğüs $(\% 31,3)$ idi. Hastaların $\% 59,5$ 'inde minör yaralanma vardı. Yaralanmaları nedeniyle hastaneye yatırılan 80 hastanın 43’ü $(\% 53,7)$ ameliyat edildi. Altı adet ölüm $(\% 3,03)$ gözlemlendi.

\section{SONUÇ}

Kendi başına saçma yaraları önemsiz gibi görünebilir, ancak, kafaya, göğüse ve karına yönelik potansiyel doku hasarına neden olabilecek yaralanmaların değerlendirilmemesi durumunda ölümcül sonuçlar ortaya çıkabilir. Hastalar, genel kurşun yaralanmaları ile aynı şekilde değerlendirilmeli ve tedavi edilmelidir.

Anahtar Sözcükler: Saçma yaraları, barutsuz silahlar.
An estimated 32,000 injuries attributable to nonpowder firearms (i.e., BB gun, pellet gun, and air rifle) occur each year in the United States, most of which are seen in the pediatric population. ${ }^{[1]}$ Many case reports of serious and even fatal non-powder firearm injuries have been published describing ocular, intracranial, abdominal, and thoracic wounds, ${ }^{[2-9]}$ but there is no single data regarding the pattern, severity and outcome of pellet injuries inflicted while controlling agitated crowds in a defined population. A persisting problem is the lack of medical recognition of the severity of injuries that can result from these guns, including penetration of the eye, skin, internal organs, and bone. Injuries associated with non-powder guns
Departments of ${ }^{1}$ General Surgery, ${ }^{2}$ Radiodiagnosis \& Imaging, ${ }^{3}$ Hospital Administration, Sher-I Kashmir Institute of Medical Sciences, Srinagar, J \& K, India.
Sher-i Kashmir Tip Bilimleri Enstitüsü, ${ }^{1}$ Genel Cerrahi Kliniği, ${ }^{2}$ Radyodiyagnostik ve Görüntüleme Bölümü, ${ }^{3}$ Hastane Yönetimi, Srinagar, Hindistan.

Correspondence (İletişim): Majid Mushtaque, M.S. Sher-I Kashmir Institute of Medical Sciences, Department of General Surgery, Srinagar, J \& K, India. Tel: +09419018445 e-mail (e-posta): drmajidmushtaque@gmail.com 
should receive prompt medical management similar to that administered for firearm-related injuries. ${ }^{[9]}$

\section{MATERIALS AND METHODS}

This study was conducted at Sher-I Kashmir Institute of Medical Sciences. The data were obtained during the period of social unrest from June 2010 to September 2010. A total of 634 patients were received in Emergency Reception (ER). Three hundred and twenty-five people sustained firearm injuries ( 88 bullet injuries, 39 tear gas shell injuries and 198 pellet gunfire injuries), Ninety-eight were injured by stone pelting and another 211 by alleged beating by the security forces. Our study included only those sustaining pellet gunfire injuries. The weapon is a pump action shotgun or pellet gun (Fig. 1), and its single shot fires numerous pellets that can hit multiple targets at once. Abstraction of information included the following: patient age, gender, anatomic location, severity of injury, diagnostic studies, treatment, and outcome including morbidity and mortality.

Upon arrival to the ER, patients were examined, primarily treated with intravenous (iv) fluids, a dose of anti-tetanus toxin, and prophylactic iv antibiotic. They also underwent the obligatory scans including X-rays [cervical spine, abdominal, pelvic and chest] and focused assessment with sonography in trauma (FAST) ultrasound scan. They were then sent either directly to the operating room, observation/disaster ward, or for additional studies such as non-contrast computed tomography (NCCT), Doppler scan, or extremity Xrays, according to their condition assessment and diagnosis (Figs. 2-6). Patients diagnosed to have minor injuries were discharged within 12 hours.

\section{RESULTS}

During the study period of four months, 198 patients were identified as having sustained pellet gunfire injury. Patients' ages ranged between 6-54 years

Table 1. Age distribution

\begin{tabular}{lcc}
\hline Age in years & $\begin{array}{c}\text { Number of } \\
\text { patients }(\mathrm{n})\end{array}$ & $\begin{array}{c}\text { Percentage } \\
(\%)\end{array}$ \\
\hline $6-10$ & 2 & $1.01 \%$ \\
$11-15$ & 14 & $7.07 \%$ \\
$16-20$ & 85 & $42.92 \%$ \\
$21-25$ & 59 & $29.79 \%$ \\
$26-30$ & 22 & $11.11 \%$ \\
$31-35$ & 6 & $3.03 \%$ \\
$36-40$ & 4 & $2.02 \%$ \\
$41-45$ & 2 & $1.01 \%$ \\
$46-50$ & 3 & $1.51 \%$ \\
$\geq 51$ & 1 & $0.50 \%$ \\
Total & 198 & $100 \%$ \\
\hline
\end{tabular}

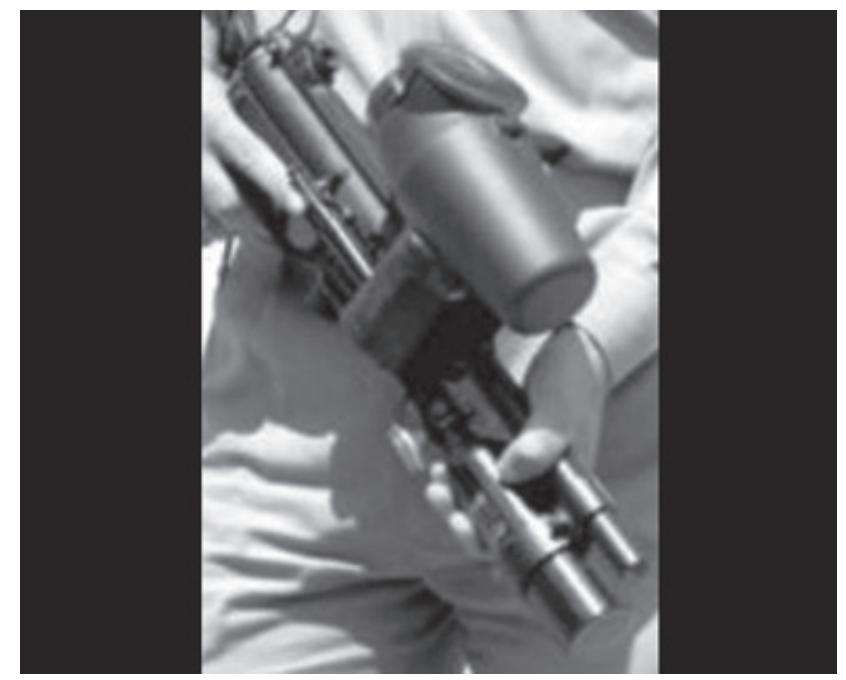

Fig 1. Pump action shotgun or pellet gun used to control agitated mobs.

(Table 1). The highest prevalence of injury was observed in the 16-25 year age group $(72.7 \%)$. The youngest patient was a six-year-old boy and the oldest was 54 years old, with pellet wounds in the face and abdomen, respectively. There were 192 males and six females. Most patients sustained multiple wounds, with up to 70 small wounds reported in one of them. The most common sites of injury were the extremities $(47.9 \%)$, abdomen $(36.3 \%)$ and chest $(31.3 \%)$. Injuries to any of these sites were associated with a significant number of injuries involving other parts of the body (Table 2).

All patients were thoroughly examined and primarily treated with iv fluids, a dose of anti-tetanus toxin and prophylactic iv antibiotic. Obligatory scans including X-rays, FAST ultrasound scan, and additional studies including NCCT, Doppler scan or extremity $\mathrm{X}$-rays were done according to the site of injury. A total of $118(59.5 \%)$ patients were found to have minor injuries and were discharged from the emergency department after antiseptic dressing or removal of the foreign bodies. Of the remaining $80(40.4 \%)$ patients admitted to the hospital for their injuries, 43 (53.7\%) required an operative procedure. The viscera damaged/injured site and the surgical procedures done are shown in Table 3. The most common sites of injuries requiring either hospitalization or operative intervention were the abdomen, chest and eyes. Operative procedures included exploratory laparotomy (20), intercostal chest tube (ICCT) drainage (9), thoracotomy (2), vascular repair/grafting (3), ophthalmic procedures (7), and exploration of neck wounds (2).

At exploratory laparotomy, the findings included isolated small gut perforations in four patients. Small gut perforation(s) were associated with large gut perforation(s) in two patients, retroperitoneal hemato- 
ma in two patients, and mesenteric hematoma, urinary bladder perforation, liver laceration, and splenic hilar injury in one patient each. Two patients had isolated colonic perforations, while another two had isolated mesenteric hematoma and gastric perforation, respectively. The operative procedures for small gut injuries included primary closure/repair in seven, resection anastomosis in four, and ileostomy in one patient. Large gut perforations were managed with repair in two, colostomy in one, and resection anastomosis in one patient. Two patients with mesenteric laceration were treated by repair in one and resection anastomosis in another. Splenic hilar injury seen in one of the patients was treated by splenectomy. Gastric perforations and liver laceration present in one each of the patients were managed by primary repair, while the urinary bladder injury was treated by primary repair with suprapubic cystostomy (SPC). No retroperitoneal hematoma was explored in our series. Four patients in our study had a negative laparotomy. One of these patients had postoperative fecal drainage via the pelvic drain on the 2 nd day. Reexploration revealed a per- foration in the posterior wall of the rectum above the peritoneal reflection, which was managed with closure and proximal diversion colostomy.

Eleven patients were treated with ICCT drainage for hemothorax/pneumothorax/ hemo-pneumothorax, of which two required thoracotomy for their persistent drainage.

Seven of 11 patients with injuries to the eyes required operative intervention. A total of five patients were blinded in the involved eye. One patient had pellet injuries in both eyes, rendering him completely blind.

Three patients required vascular repair of femoral or popliteal vessels, and another two were subjected to exploration of neck hematoma revealing injury to the trachea and one of the carotids.

Mortality occurred in six patients (3.03\%). Five of these patients died either in the emergency OT or in the immediate postoperative period. One died of sepsis on the 7th day. Wound infection was seen in eight

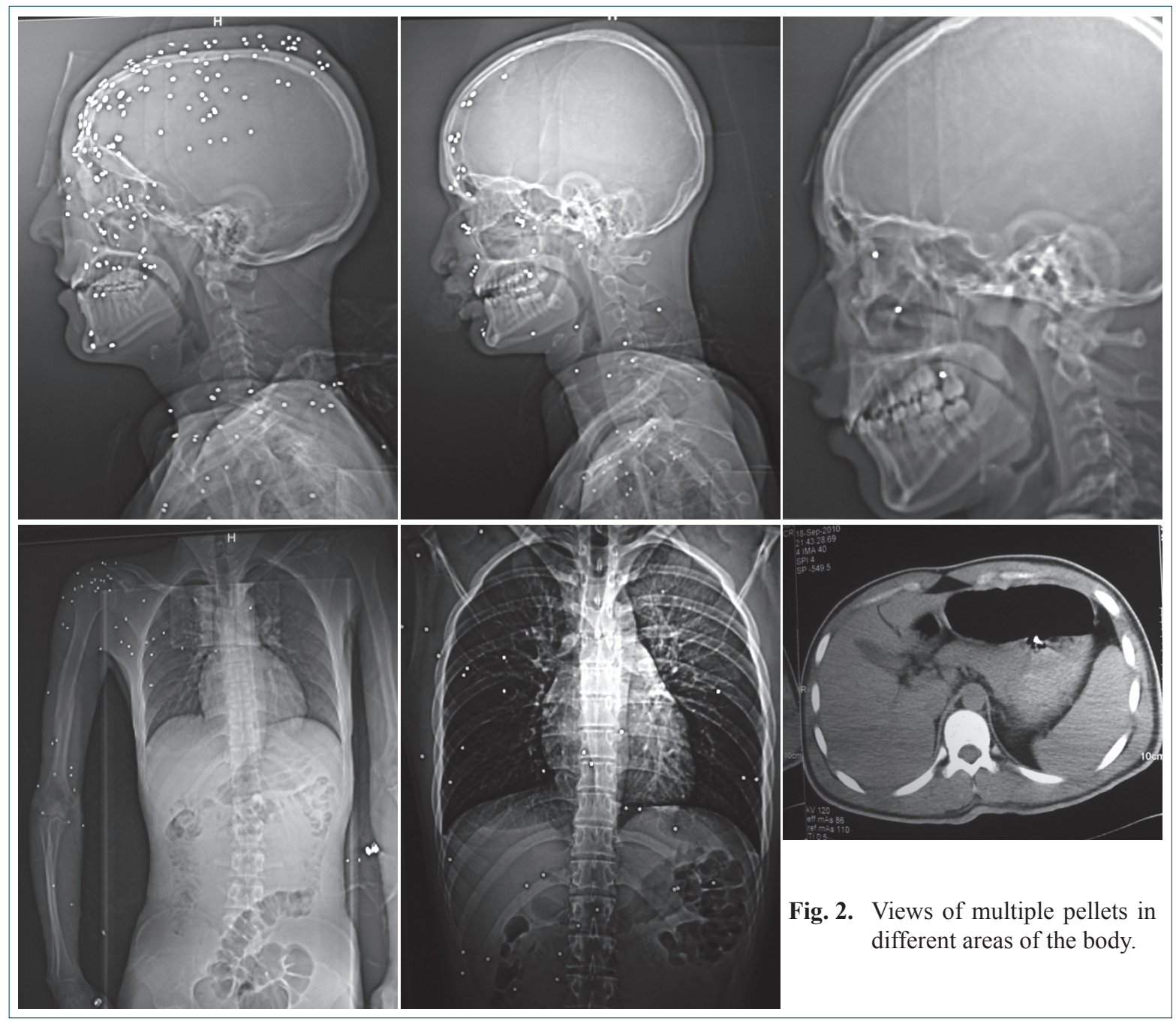


Table 2. Anatomical site of injuries

\begin{tabular}{lcccc}
\hline Site of injury & \multicolumn{2}{c}{ Number of patients } & Total & $\begin{array}{c}\text { Percentage } \\
\text { Isolated to the site }\end{array}$ \\
\cline { 2 - 3 } & $\begin{array}{c}\text { Associated with injury to } \\
\text { other sites }\end{array}$ & & \\
\hline Head and neck & 31 & 11 & 42 & 21.21 \\
Face and eyes & 21 & 2 & 23 & 11.61 \\
Chest & 35 & 27 & 62 & 31.31 \\
Abdomen & 38 & 34 & 72 & 36.36 \\
Extremities & 73 & 22 & 95 & 47.97 \\
\hline
\end{tabular}

Percentage does not correlate to $100 \%$ because of multiple injuries present in majority of the patients $(n=198)$.

of the operated patients (18.6\%). Two patients had adhesion obstruction that was managed conservatively.

\section{DISCUSSION}

A number of firearms have been used to disperse/ control violent mobs in Kashmir over the last 20 years. These include conventional bullets, rubber bullets, and tear gas shells. Pellet firearms have been introduced as the latest modality for crowd control, assuming to have lower mortality. There are two injury patterns that result from pellets: minor, requiring local care in the emergency department with subsequent discharge, and serious, requiring admission to the hospital and frequently operative intervention. Serious injuries occasionally cause long-term functional deficit. Nonpowder firearms can generate muzzle velocities of 200 to 900 foot-pounds per second; ${ }^{[7]}$ skin penetration requires only 120 foot-pounds per second, ${ }^{[4]}$ while ocular penetration can occur at velocities as low as 130 $\mathrm{ft} /$ second. ${ }^{[9]}$ Fortunately, the majority of these injuries are minor (59.5\% in this series).

There is a potential for serious injury, which mandates that all non-powder firearm wounds be thoroughly evaluated to avoid missing underlying severe injury. This should include localization of the foreign body, if present, in three dimensions using imaging techniques (typically roentgenograms), determination of the trajectory to postulate the potential organs injured, and assessment of the need for operative intervention. Wounds determined to be minor should receive local wound care (irrigation, removal of foreign body if superficial), and tetanus prophylaxis. Antibiotics are not required routinely, but their use should be at the discretion of the treating physician. Antibiotics are typically reserved for patients with additional risk factors for wound infection (i.e., tissue devitalization, delay in treatment, or gross contamination).${ }^{[5]}$ All the patients in our series received prophylactic antibiotics, as most of them had contamination. Patients with potentially serious wounds should be admitted for observation, and if indicated, operative intervention.

In our series, the extremities were the most common site involved (47.9\%), and only three patients required admission and operative intervention for vascular injuries. The majority of the extremity wounds required only local wound care, careful neurovascular

Table 3. Showing various viscera damaged and surgical procedure done

\begin{tabular}{|c|c|c|}
\hline Viscera damaged/Injured site & Number of patients & Surgical procedure \\
\hline Small gut perforation & 11 & $\begin{array}{l}\text { Repair in } 7 \text {, resection anastamosis in } 4 \text {, } \\
\text { and ileostomy in } 1 \text { patient. }\end{array}$ \\
\hline Large gut perforation & 4 & $\begin{array}{l}\text { Repair in } 2 \text {, colostomy in } 1 \text { and } \\
\text { resection anastamosis in } 1 \text { patient }\end{array}$ \\
\hline Mesenteric laceration & 2 & Repair in 1 and resection-anastamosis in 1 patient \\
\hline Splenic hilar injury & 1 & Splenectomy \\
\hline Urinary bladder laceration & 1 & Repair with SPC \\
\hline Gastric perforation & 1 & Primary repair \\
\hline Liver laceration & 1 & Primary repair \\
\hline Negative laparotomy & 4 & Missed rectal perforation \\
\hline Re-exploration & 1 & ICCT drainage only in 9 \\
\hline Thoracic wounds & 11 & and thoracotomy in 2 patients \\
\hline Vascular injuries in extremities & 3 & $\begin{array}{l}\text { End to end anastamosis in } 2 \text { and vascular grafting in } \\
1 \text { patient }\end{array}$ \\
\hline Ophthalmic procedures & 7 & \\
\hline Neck wounds & 2 & Carotid a repair in 1 , and tracheal repair in 1 patient \\
\hline
\end{tabular}


evaluation, and tetanus prophylaxis. This is in accordance with the consequences of non-powder firearm injuries reported previously. ${ }^{[7]}$

Abdominal injury occurred in 72 patients, of whom $20(27.7 \%)$ required laparotomy for signs of peritonitis and/or hemoperitoneum. The small gut was the most common viscera injured. Four patients had a negative laparotomy. One of these patients had postoperative fecal drainage requiring reexploration. We stress the importance of a thorough inspection of all the abdominal viscera in patients sustaining pellet wounds to the abdomen, as small perforations may be missed easily and present with complications. Bond et al. ${ }^{[10]}$ also described in their study that abdominal wounds were frequently associated with visceral injury and multiple perforations, usually of the small bowel, and peritoneal penetration was associated with a more than $80 \%$ chance of visceral injury.

Thoracic injury occurred in $62(31.3 \%)$ patients, of whom operative intervention was required in 11 $(17.7 \%)$. Most of these patients were managed with ICCT drainage, while two required a thoracotomy for persistent drainage. No patient in our series had cardiac injury, which could be rapidly fatal. The potential lethal nature of these wounds is reported by Scribano et al., ${ }^{[7]}$ who evidenced a child sustaining right ventricular penetration and presenting with pericardial tamponade. Others reported similar experiences including cardiac penetration with pellet embolization and aortic penetration with delayed cardiac arrest and death. ${ }^{[11]}$

Although 42 (21.2\%) patients in our study had pellet wounds in the head and neck region, only two $(4.7 \%)$ required operative intervention. None of the patients had intracranial penetration of the pellet, which is also a possibility, with its attendant risk of morbidity and mortality. ${ }^{[12]}$ Ocular and facial injuries, in contrast, occur less frequently, but were seen in $23(11.6 \%)$ patients. Eleven of these patients had penetrating ocular injury, seven required operative intervention, and six $(54.5 \%)$ had residual functional deficits. This is in accordance with the consequences of non-powder firearm ocular injuries reported previously. ${ }^{[3,6]}$

Deaths attributable to non-powder firearms have been reported in previous case reports. Most of these studies have been done in the pediatric population $^{[4,7,8-12]}$ and are the result of unintentional/sports-related non-powder firearms injuries. The lethal poten- tial of these wounds is difficult to quantify due to the paucity of large reported series; however, this should not diminish the concern in the evaluation of these patients. ${ }^{[7]}$ There were six deaths in this series. Pellet gun (pump action short gun), though considered as a new benign modality (non-lethal weapon) for controlling agitated crowds, is not really benign. It can cause serious injuries with morbidity and mortality.

Pellet guns either should not be used to disperse agitated mobs unless extremely necessary, or the personnel using them might be better trained so that the people do not receive close hits. While the pellet wound itself may seem trivial, if not appreciated for the potential for tissue disruption and injuries to the head, chest, and abdomen, there can be catastrophic results. Patients should be evaluated and managed in the same way as those sustaining bullet injuries.

\section{REFERENCES}

1. McNeill AM, Annest JL. The ongoing hazard of BB and pellet gun-related injuries in the United States. Ann Emerg Med 1995;26:187-94.

2. Annest JL, Mercy JA, Gibson DR, Ryan GW. National estimates of nonfatal firearm-related injuries. Beyond the tip of the iceberg. JAMA 1995;273:1749-54.

3. Smith D, Wrenn K, Stack LB. The epidemiology and diagnosis of penetrating eye injuries. Acad Emerg Med 2002;9:20913.

4. Fernandez LG, Radhakrishnan J, Gordon RT, Shah MR, Lain KY, Messersmith RN, et al. Thoracic BB injuries in pediatric patients. J Trauma 1995;38:384-9.

5. Wascher RA, Gwinn BC 2nd. Air rifle pellet injury to the heart with retrograde caval migration. J Trauma 1995;38:379-81.

6. Girdler NM. Facial airgun wound. J Trauma 1995;38:3901.

7. Scribano PV, Nance M, Reilly P, Sing RF, Selbst SB.Pediatric nonpowder firearm injuries: outcomes in an urban pediatric setting. Pediatrics 1997;100; 5.

8. Powell EC, Sheehan KM, Christoffel KK. Firearm violence among youth: public health strategies for prevention. Ann Emerg Med 1996;28:204-12.

9. Laraque D; American Academy of Pediatrics Committee on Injury, Violence, and Poison Prevention. Injury risk of nonpowder guns. Pediatrics 2004;114:1357-61.

10. Bond SJ, Schnier GC, Miller FB. Air-powered guns: too much firepower to be a toy. J Trauma 1996;41:674-8.

11. Suchedina AA, Watson DC, Alpert BS, Di Sessa TG. Cardiac injury from an air gun pellet: a case report. Am J Dis Child 1993;147:262-3.

12. Myre LE, Black RE. Serious air gun injuries in children: update of injury statistics and presentation of five cases. Pediatr Emerg Care 1987;3:168-70. 